\title{
13 Beyond single modes and media: Writing as an ongoing multimodal text production
}

\begin{abstract}
In this chapter, we focus on new, hybrid forms of text production and their research. We start from the practical example of Wikipedia, and the ways in which articles are developed quickly and then refined over time by Wikipedians (Part 1). This approach illustrates transitions from a narrow to a broader orientation in writing research (2). We then develop a framework for the state-of-the-art analysis of writing as a focused and incidental, by-the-way activity of producing editable and storable multimodal communication offers (3). Within this framework, challenges for and controversial issues of contemporary writing research can be identified (4). This allows us to outline what such research can contribute to Applied Linguistics (5) and to sketch a related research roadmap (6). Finally, in the reference section, we list key publications that explain writing research beyond single modes and media (7).
\end{abstract}

\section{From focused writing to writing-by-the-way - introductory example}

Intentional, organized, and efficient writing has long been a key competence of academic and professional life: people sit down at their desk or another comfortable space in order to write a good text. They use pen and paper, a typewriter or a computer, and start with a draft. Then, they edit their text until they consider it complete. Finally, they send it off or publish it as a carefully designed piece. Unlike speech, it is decoupled from traces of fighting with thoughts and words - a close-to-perfect communicational offer. For the purposes of our argument, this conventional way of producing texts can be termed focused writing, a type of production that takes place over some span of time and with some degree of revision. Whether it is an email that takes just a minute, or a book that takes a lifetime, any type of focused writing still involves a recursive process. The final products of focused writing - essays, reports, letters, stories, poems, blog posts, books, and more - remain the currency of highquality composition for school, work, and the community.

Digitalization, mediatization, and glocalization (Khondker 2004), however, are increasing the necessity to communicate with writing in new, hybrid forms. These forms transgress traditional boundaries between speech and text - often incorporating audio, video, and still images with the written word - as well as between private, educational, and professional domains (Oakey and Russell, this volume). Using mobile interfaces to global networks, individuals and organizations communicate across cul- 
tures and languages. In an increasingly dynamic world, people synchronize knowledge, share emotions, and maintain identities from any location and at all times of the day. In what could appear to be a stark contrast to focused writing, this new communication activity can be conceptualized as what we will term writing-by-the-way.

While writing has always been an activity that, in some way or another, involves a writer, a message, a medium, and a reader, we concur with scholars who have noticed both qualitative and quantitative changes in the ways most people communicate with writing-by-the-way in today's global infrastructure. Through the use of mobile phones, SMS, Twitter, social networking, and new content added to millions of websites each day, people are now sharing both more focused writing than ever before, and certainly more writing-by-the-way. For instance, recent survey results from Pew Internet suggest that $78 \%$ of American teens have a cell phone and that $95 \%$ use the Internet on a regular basis (Madden et al. 2013). The United Nations' International Telecommunications Union (2013) reports that the number of people online is approximately 2.7 billion (although disparities do exist between the number of men and women online, as well as between developed and developing nations). Still, as more and more of the world and its young people move online, a growing number of our citizens add plenty of digital writing (and, oftentimes, digital detritus) to the global river of information.

Broadly, these types of literacy practices, largely enabled by technology (Dale and Mahlow, this volume), have been identified in a variety of ways as the idea of text has expanded in recent decades. Scholars continue to explore the ways in which visual and digital texts function, both in terms of hybridity as well as in terms of designs of meaning. The New London Group, for instance, includes the study of linguistically and culturally diverse texts, as well as "text forms associated with information and multimedia technologies" under the term "multiliteracies" (Cope, Kalantzis, and New London Group 2000: 9). Lankshear and Knobel have described "new literacies," which include both emerging technologies as well as shifting mindsets about literacy practices that these newer technologies encourage (Lankshear and Knobel 2003, 2007, 2011). Other terms such as digital, critical, and 21st century literacies have been employed by various scholars, teachers, and professional organizations in various curricula, reports, journal articles, conferences, and textbooks. More recently, Avila and Panyda have introduced a new term, "critical digital literacy," which encompasses "those skills and practices that lead to the creation of digital texts that interrogate the world" (Ávila and Pandya 2012: 3). All digital writing activities continually leave traces in digital databases. No matter what people click, drag, drop, speak or type, it remains there, adding up to huge plasma-like metatexts over time.

Such properties of traditional and new forms of writing can be evaluated, based on empirical data, and optimized, for example, through education and mentorship. By using focused writing and writing-by-the-way to lay out this chapter, we offer them up not as dichotomies, but as a duality that we, as scholars of language, must come to understand in our own work. 
Wikipedia, as one of the world's most trafficked websites, provides a unique case study for looking at the history and value placed on focused writing and how it intersects with writing-by-the-way. Far from being a series of random edits that lacks serious journalistic and academic integrity, Wikipedia has grown from its humble beginnings in January of 2001 to become both a space for writers to compose as well as a space for understanding how writing is composed. In this sense, it forms an interesting hybrid of focused writing and writing-by-the-way, worthy of our attention as scholars, teachers, and writers.

First, a bit of history. As many web users know, Wikipedia received a great deal of attention around 2005 as it became a popular destination for the casual internet surfer, students looking for quick nuggets of information, and, to a lesser degree, scholars interested in very specific topics. The structure of a wiki, as a particular type of website that is easily editable by even anonymous users, provided writers with the opportunity to contribute information to a valuable resource. Wikipedia began, then, in a spirit of collaboration, as a web-based encyclopedia called NuPedia that would rely on the skills of hundreds, perhaps thousands of writers and editors. While there have been some controversies surrounding it, most notably from journalists and academics worried about the quality of information available on the site, Wikipedia held its own versus the more traditional encyclopedia, Britannica (Goodin 2005), and has demonstrated, again and again, the value that multiple authors can bring to a single article.

Still, Wikipedia is sometimes dismissed as inaccurate or biased, leading numerous educators to ban its use by students. This critique, according to media scholar Clay Shirky, misses the broader social and collaborative purpose of Wikipedia.

\footnotetext{
You cannot understand Wikipedia (or indeed any large social system) by looking at any one user of even a small group and assuming they are representative of the whole. The most active few users account for a majority of the edits, even though they make up the minority, and often a tiny minority, of contributors. But even this small group does not account for the whole success of Wikipedia, because many of these active users are doing things like correcting typos or making small changes, while users making only one edit are sometimes adding much larger chunks of relevant information (Shirky 2008: 127-8).
}

As a community of writers and editors committed to accuracy and a "neutral point of view" (Wikipedia 2013b), Wikipedians create an ever-changing text where factual information is presented on the main page for any topic, without bias, and debates about how that information is presented happen on a mirroring discussion page. Each contributes what he or she can, be that substantive amounts of new information or substantive knowledge of language in the editing process. Writing-by-the-way can, over time, contribute to a piece of focused writing which, in turn, is always open for revision.

Thus, as a space for focused writing, Wikipedia provides the world with a public view of almost any topic that contains relevant and up-to-date information, as well 
as links to outside sources. Given the ever-increasing number of individual blogs and news media sources with a particular political slant on any given topic, Wikipedia offers its visitors - nearly 500 million a month (The Wikimedia Foundation, n.d.) - clear, concise, and, for the most part, referenced information. For topics that contain unverified information, the page will clearly indicate that sources need to be checked, a cue both to the casual browser and Wikipedia's writers and editors so anyone reading understands that there is more work to be done. This is an intellectual challenge for writers, not just a place for hobbyists to post information about their niche topics or some malicious person to spread libelous rumors. By writing for Wikipedia, Martin Poulter, PhD, claims that "I forced myself into both good scholarly habits and accessible writing” (Poulter 2012). Focused writing, created collaboratively by a worldwide team of authors and editors, forms the core of Wikipedia's public face.

Concurrently, as a space for writing-by-the-way, Wikipedia - with its particular web-based backbone being a wiki and its community ethos noted above - provides us with insights into how both technical and social forces combine to become more than the sum of their parts. As noted, since it is a public space for writing, most Wikipedia articles are open for editing by any web user, although some sensitive topics require that a writer create an account (Wikipedia 2013a). Still, some edits are minor and some are considerable, depending on the interest and expertise of the writer. Also, by default, each Wikipedia page has an accompanying “Talk" page, as well as a "History" page. The talk pages are the heart of the Wikipedia community, allowing writers and editors to have discussions about the topic, determining what information to present on the main page and how best to share it. The history page, too, offers insights into the writing process as it happens. Every time a user saves a new version of the page, the history page saves a snapshot of the previous version, allowing anyone the opportunity to compare the current version of the page with past versions. While some revisions are simple editing of spelling or punctuation, other revisions can show significant additions to the text of the main page. Both the talk and history pages serve as spaces for writing-by-the-way that, in turn, leads to the focused writing on the main page.

In sum, Wikipedia offers us a unique look at both focused writing - in the form of individual pages on thousands of topics - as well as writing-by-the-way - in the form of accompanying talk and history pages for every topic. Further disagreements about the absolute veracity of any given Wikipedia article aside, we can see that the technical affordances of the wiki platform makes such writing possible, and the community of Wikipedians maintain an ethos about the writing that translates into information on the site. For both focused writing that forms the public face as well as the writing-by-the-way that allows the community to function, Wikipedia represents one space for us to consider the affordances of textual production that moves beyond one author, and the singular use of alphabetic characters. Indeed, Wikipedia actively moves beyond single modes and media, involving both focused writing and writingby-the-way as well as combining written language with visual and audible informa- 
tion. A more thorough understanding of how these overlapping processes works, from various theoretical understandings that could guide us as researchers, now follows.

\section{Whatever you can edit: A brief history of writing in a broad sense}

As Wikipedia illustrates, our romanticized vision of a single author working alone at his or her desk needs to be reconsidered in order to fully understand how writing functions in our world today (Schindler and Wolfe, this volume). Our ever-emerging understanding of what writing is and how it functions in the world can be traced through a number of scholarly traditions, which are related to applied linguistics in various ways. Key agents include scholars in the rich history of Sociolinguistics (2.1), New Literacy Studies (2.2), and Digital Writing and Rhetoric (2.3). More recently, an emerging field of Digital Humanities has begun to take shape (2.4). We will explore each briefly below, noting that this cursory overview is, of necessity, incomplete. Yet, we hope it will still provide enough background for us to further consider the topic of this chapter: the evolution of writing to move beyond single modes and media.

\subsection{Sociolinguistics}

Building on the early work of Currie (e.g., 1959), Fishman (e.g., 1972), Hymes (e.g., 1972), or Labov (e.g., 1972), sociolinguistics has emerged at the intersection of anthropology, ethnography, and, more recently, the study of social networks. For scholars interested in the connections between language, class, culture, and education, Shirley Brice Heath's Ways With Words (Heath 1983) was the breakthrough study, demonstrating the power of language to shape, and be shaped by, those who use it. Over the next two decades, even more accounts of how individuals and communities use language emerged, and James Paul Gee posed a distinction between "capital D" types of "Discourses" - the types that held and maintained power - and regular "discourses" (Gee 1996). Additional ethnographic work yielded further insights into the power of language across racial and socio-economic classes, and especially in relation to educational achievement (e.g., Anyon 1997; Barton and Hamilton 1998; Dyson 2003; MacLeod 1995). The politics of language still bleed into issues of race, class, and gender throughout the world, encouraging linguists to understand and explain differences in languages and dialects, especially in cases where Standard English is considered a Discourse of power and privilege (Delpit 2006). Thus, sociolinguistics contributes to our understanding of focused writing and writing-by-the-way by investigating the way that power, cultural, and identity is represented in language. 
In the example of Wikipedia, we see how traditional academic discourses and power structures that value the production and dissemination of knowledge through various gatekeepers - academics, editors, clergy, politicians, journalists, military and corporations, to name but a few - are disrupted by the way in which Wikipedians coconstruct and share knowledge. Through an interactive process of writing-by-the-way, each page on Wikipedia becomes a piece of focused writing through a collaborative bottom-up process. However, because the way in which that writing comes into being differs so drastically from more traditional (and mostly top-down) forms of knowledge construction, resistance comes from those who are still trying to understand how a piece of writing produced in such a fashion could possibly be accurate. Thus, Wikipedia offers to sociolinguists an exemplary space for investigating negotiation through focused writing and writing-by-the-way. Understanding when, why, and how certain materials make it into the front page of a Wikipedia article could provide for a rich space of writing research from a sociolinguistic perspective.

\subsection{New Literacy Studies}

At the same time Heath published her groundbreaking work (Heath 1983), Brian Street introduced the idea that "literacy" is not a static entity, exactly the same across all individuals and in all contexts. In particular, technologies affect literacy in a complex way.

But literacy, of course, is more than just the 'technology' in which it is manifest. No one material feature serves to define literacy itself. It is a social process, in which particular socially constructed technologies are used within particular institutional frameworks for specific social purposes (Street 1984: 97).

Since then, New Literacy Studies have investigated language use in particular contexts, especially those enabled by technology. As Mills reports, "Scholars within the New Literacy Studies have specifically drawn attention to the innovative and productive potentials of literacy practices in electronic environments that children use both in and out of school settings" (Mills 2010: 247). In a more recent turn, the so-called new literacies have been described through a variety of overlapping and related terms such as 21st century literacies, digital literacies, multiliteracies, information literacy, information and communication technologies (ICT) literacies, new media literacies and, as noted below, digital writing and rhetoric. In each of these descriptions, the focus is both on the social practice involved in communicating as well as the use of particular technologies for doing so. Knobel and Lankshear, among others, focus on these social practices that newer technologies enable such as fan fiction, discussion forums, and multimodal text production, for example of videos and websites. Also, they are critical of formal attempts to "teach" new literacies 
Insofar as schools try to get to grips with the changing world of literacy and technology (often seen in terms of using computers in the production of texts and textual representations), they often simply end up reproducing familiar conventional literacies through their uses of new technologies (Lankshear and Knobel 2007: 30).

As with Sociolinguistics, then, scholars interested in new literacy studies and the study of new literacies are interested in power, privilege, and how language can be used for various purposes. New Literacy Studies contribute a theoretical perspective to writing-by-the-way in that this type of writing involves various technologies and has the potential to communicate messages to a broad audience of readers. Yet, this writing can become focused, too, over time and in the social process of response and revision. In the same manner that Sociolinguistics examines the power and influence of particular actors in language events, those interested in New Literacy Studies are interested in the ways that writing and multimodal media can be produced, circulated, responded to, and revised using various technologies enabled by the internet and digital, mobile networks in general.

Wikipedia offers scholars who take a new literacies perspective a space to study focused writing and writing-by-the-way, working to understand how the technological backbone of a wiki helps facilitate this process. Given that each page is editable, and that each page has its history tracked from version to version, the technology itself opens a wiki page up to collaborative construction. At the time Wikipedia was introduced, documents could not be edited simultaneously or in any easy fashion. While that has changed with advances such as collaborative word processing through cloud based computing, these documents are still usually not made as public as a page on Wikipedia, which continues to open itself up to additional revision. Thus, observing the ways that Wikipedians utilize writing-by-the-way technologies of editable pages, revision histories, and additional discussion pages to develop a shared piece of focused writing might be of interest to those scholars approaching the task from a new literacies perspective.

\subsection{Digital Writing and Rhetoric}

Since the first publication of the journal Computers and Composition in 1983 and the online journal Kairos in 1996, the field of composition and rhetoric has increasingly acknowledged the ever-growing influences of technology on both writers and writing. Each of these journals - along with hundreds of other peer reviewed articles and scholarly books - have in the past 30 years taken up related topics of writing with word processors, then on the internet, then with additional attention paid to graphical elements such as fonts, color, and image, and more recently on topics related to the interactive nature of web-based writing. One definition of digital writing describes it as 
compositions created with, and often times for reading or viewing on, a computer or other device that is connected to the Internet (DeVoss, Eidman-Aadahl, and Hicks 2010: 7, emphasis in original)

In addition to the tools needed for such digital writing, writers also need to understand their audience, purpose, and context. This leads us to also explore the related concept of digital rhetoric which

constitutes communicative acts that may include text, visual elements, and sounds. It concerns usability, as viewers/readers/users must be able to navigate information for a given purpose to be fulfilled. Digital rhetoric moves the purposeful communication off of the page and into systems, pictures, and electronic devices. (DigiRhet.org 2006: 243)

Much like those interested in New Literacy Studies, scholars of Digital Writing and Rhetoric are interested in the ways that social and technological aspects affect writers' decision-making, although their interest is more rhetorically-focused. For instance, while a scholar of New Literacy Studies might be more interested in the social processes involved in creating a Wikipedia article, a scholar of Digital Writing and Rhetoric might focus attention on the actual text itself. These boundaries, like all writing in our current age, are blurry. Still, those interested in digital writing draw from the rich history of composition and rhetoric to better understand the decisions that writers make when being intentional and choosing to craft particular pieces of digital writing such as websites, presentations, video, or social media for specific audiences and purposes (Hicks 2013).

Thus, Digital Writing and Rhetoric provide us with another important theoretical lens to bring into consideration. They focus on the design aspects of writing and text production, ranging from the broad scope of document design to the ways that individual sentences are created, right down to the specific words that are chosen. For instance, Wikipedians strive to provide reliable, neutral descriptions of each topic Wikipedia covers. Often, a viewer may find a notice at the top of a Wikipedia page stating that further research needs to be done to support the ideas presented in the existing text. More importantly, the references that are inserted as footnotes in a Wikipedia page's main text are then listed at the bottom of the page, with hyperlinks to sources outside of Wikipedia. Within the article, however, all links are to other pages on Wikipedia. Why and how a particular Wikipedian may choose to insert a reference - both internally and externally - would be of interest to a digital rhetorician. On the one hand, for instance, when is a reference to an internal Wikipedia page (itself with many external links) enough of a citation? On the other, when must a Wikipedian cite an outside source in order to maintain credibility? The choices about hyperlinks as a specific, linguistic decision would be of particular interest to scholars of Digital Writing and Rhetoric who want to understand how a focused piece of hypertextual writing is developed over time. 


\subsection{Digital Humanities}

While the study of humanities has always included words as well as images, paintings, music, sculpture, and any number of other art forms, it is the vast number of changes in technology over the past twenty years that have given rise to what has come to be termed Digital Humanities. There appears to be two broad approaches to inquiry in the digital humanities. First, because so many programs, websites, and tools enable products now to be born digital, there are new pieces of writing, art, photography, and so on that have been developed which could not have existed before. Second, newer and more powerful digital tools have given rise to new forms of inquiry. For instance, corpus linguists can use databases of language examples to generate patterns about how certain words and phrases have been used over time. Also, these digital tools allow us to look more closely at existing material products which can be digitized for further analysis. For instance, few of us are likely to ever be able to physically see or touch the Dead Sea Scrolls or a Gutenberg Bible, but anyone can view these timeless artifacts online. New digital tools, again, allow us to create new artifacts as well as analyze those pieces that already exist in the world.

Digital Humanities is a broad field. The Alliance of Digital Humanities Organizations (ADHO) - which includes members from Europe, Canada, Australia, and Japan - describes its member organizations' interests as including:

"textual analysis, electronic publication, document encoding, textual studies and theory, new media studies and multimedia, digital libraries, applied augmented reality, interactive gaming, and beyond" (Alliance for Digital Humanities Organizations, n.d.).

Another organization based in the United States, HASTAC (Humanities, Arts, Science, and Technology Alliance and Collaboratory) describes itself as

"an alliance of individuals and institutions inspired by the possibilities that new technologies offer us for shaping how we learn, teach, communicate, create, and organize our local and global communities” (Humanities, Arts, Science, and Technology Alliance and Collaboratory, n.d.).

While both organizations are still young (ADHO began to form in 2002, and HASTAC officially formed in that same year), a growing emphasis on the digital humanities has brought together computer scientists with lovers of language, art, and music through conferences, publications, and competitions. A number of writing-related projects have been undertaken by scholars in the digital humanities, including corpus linguistics, new media, multimedia literacy, and electronic literature.

Digital humanities, thus, contributes to our understanding of both focused writing and writing-by-the-way in that we have a variety of research tools and methods for reviewing existing forms of writing, and for capturing writing in the future. Returning to Wikipedia, a linguist who wants to study language use might be interested in the ways that particular topics are represented through various related word choices. 
By downloading the full text of numerous Wikipedia articles, for instance, we could look at instances of the word writing as a noun or as a verb, and in relation to other terms such as writing process, craft of writing, or whatever else might be of interest. Of course, this is but one approach in a field that also includes those interested in typography, design, and other aesthetics, which could lead to a study of how images are employed on Wikipedia pages. Certainly, analysis and critique of existing works of art remain a popular pursuit in the humanities as well, and Wikipedia offers space for such conversations, too.

Taking together the various epistemologies embodied in Sociolinguistics, New Literacy Studies, Digital Writing and Rhetoric, and Digital Humanities, we can infer broad implications for both focused writing and writing-by-the-way in our increasingly networked world, a task we turn to in the next section.

\section{State-of-the-art framework: Five dimensions of writing beyond modes and media}

As we have made clear up to this point, and will return to again in Part 6, we see focused writing and writing-by-the-way as working in conjunction with one another, more so now in our increasingly technologized worlds. Much like the Council of Writing Program Administrators, the National Council of Teachers of English, and the National Writing Project in the US who have created a list of "habits of mind" for college- and career-ready writers (2011), what we will describe below as our dimensions of writing will refer to a richer, more nuanced understanding of the writing processes in contemporary environments rather than any particular text products. Having examined Wikipedia as an exemplary case of focused writing and writing-bythe-way, as well as looking at four complementary theoretical perspectives to inform our thinking, we now outline five procedural dimensions of how writing can currently be perceived, researched, and enacted through scholarship, curriculum, instruction, workplaces, communities, and virtual spaces. The five dimensions are deliberateness (3.1), inclusiveness (3.2), connectedness (3.3), versatility (3.4), and openness (3.5).

\subsection{Deliberateness}

Deliberateness foregrounds the notion that contemporary writing is an intentional, focused, and long-term activity as well as a thoughtful, incidental activity.

Writing, in many ways, has been contrived as a school subject in order to get students to produce uniform drafts or prose. Yet, when we read the work of our greatest 
writers - and their reflections on their life as writers - we understand that writing works as a mode of self-expression and reflection, writing can affect civil and societal discourse, and writing is a means of discovery and a way to produce knowledge. Writing can be utilitarian, of course, whether as focused writing or writing-by-theway. Students, for example, still compose traditional academic essays, and salespeople still engage in traditional business correspondence.

Yet, both groups also understand when and how to move into more complex and dynamic genres (e.g., Wright 2012; Yang 2012), both from a technical standpoint (websites, presentations, videos and other multimodal compositions) as well as a rhetorical standpoint (paying attention to complex, dynamic audience, purpose, and context and hypermedia environments). Examining the ways that writing-by-the-way can be shaped as determined activity and, over time, lead to focused writing helps us better understand, for example, the effect of having, as a writer, the purpose and audience in mind, even when the communicative act may be very brief.

\subsection{Inclusiveness}

Inclusiveness foregrounds the notion that contemporary writing is a metaphor for producing and editing verbal data, but also audio and video files, and that it is deeply intertwined with reading, speaking, and listening.

As noted above (2.3), scholars have begun to examine composition as an act that happens across multiple modes and media. Writing has long been reflected "in the perspective of speaking" (Chafe 2002: 43), for example as a means to prepare oral presentations such as public speeches or news voiceovers. Second, writing has, through calligraphy, typography, and layout, always included paraverbal and nonverbal aspects (e.g., Ludwig 2005). Third, written texts have long been illustrated with drawings, figures, and, more recently, info-graphics (e.g., Knox 2009; Weber and Rall 2012).

However, the digital environment intensifies the inclusiveness of writing. Even in something as seemingly simple as a Twitter message, limited to 140 characters, a writer must make a vast number of decisions: will it include an "at reply" (using the @ character) to cite another Twitter user? Will it include a hashtag (using the \# character) to connect to a broader conversation or indicate humor or sarcasm? Will it include a picture, a short video clip, or a geotag for location? Or, will it include a link to another web-based document such as a news item or blog post? Even in composing a short message as writing-by-the-way, participating in broader social networks entails focused attention and effort. This encourages scholars, teachers, and facilitators in professional education to research these forms and to expand their view of writing to include other modes and media not traditionally associated with school and the workplace (e.g., Perrin 2012). 


\subsection{Connectedness}

Connectedness foregrounds the notion that contemporary writing is oriented towards explicit intertextuality, as embodied for example in hypertexts, text ecologies, and databases.

Formerly a decision to be made between handwriting and composing with a typewriter or wordprocessor, the fundamental decisions that writers now face begin on screen: will this be primarily public or private? Authored alone, or with collaborators? Will it ultimately be a print-based, seemingly linear text (albeit probably stored and linked in electronic databases)? Will it be an explicit hypertext that relies on links, embedded media, and the structural opportunities available when composing for example in HTML - or will it be something "after hypertext" (Johnson-Eilola and Kimme Hea 2003: 415)?

Hypertextual writing, then, is about more than making hyperlinks; it involves a series of sophisticated decisions that a writer must make in terms of the content she creates as compared to what she reuses. Moreover, once a hypertext is produced, the links will create a new experience for each reader. Complex connections enhance the complexity of navigation and, therefore, the dynamics of reading. Hypertexts allow for, and trigger, multitudes of potential ways of uptake. This requires modular text design and writing. How a writer balances those demands and makes choices about textual production is one of the essential questions for writing research and teaching in our era.

\subsection{Versatility}

Versatility foregrounds the notion that contemporary writing results in transient text in interactive online environments, accessible through versatile and dynamic layouts on variegated devices such as small and big screens.

Whereas most media converge towards digital formats and mobile global access, they diverge, at the same time (e.g., Singer 2009), in terms of user interfaces such as screen size or interaction modes (e.g. touchscreen, voice control). Newer technologies, including both hardware and software, allow for different approaches to creating and sharing writing. The affordances and constraints of particular environments and the ways in which writing appears (or disappears) in those spaces can matter a great deal both to the writer and the reader. For instance, a recent blog post will show up in a user's RSS feed as well as on the actual home screen of a particular blog, whereas an older post could require the reader to scroll down to search for through an archive.

Because many of the design features of web-based texts (such as font, color, size, headings, italics/bold) have been separated from the actual text itself through the use of tools such as cascading style sheets (CSS) and extensible markup language 
(XML), any particular word or sentence that a writer puts into a blog post could look quite different depending on the size and shape of the screen on which it is viewed. This creates a number of opportunities and challenges for both focused writing and writing-by-the-way in that a writer must be thinking not only about the content of his message, but how that message could potentially be seen on both existing and future types of screens or visual displays.

\subsection{Openness}

Openness foregrounds the notion that contemporary writing tends to address an unlimited readership in an unlimited timeframe, transcending boundaries between formerly strictly separated entities such as authors and readers, individual and collective addressees, and private and public access.

When writing for various global networks that run on and through social media, search engines and databases, a writer must make many decisions about how to share her work. Will the work be on her personal blog, in a peer reviewed journal, or on website fueled by citizen journalism? Must the work have the stamp of approval from an official media channel or academic publisher? Or, is the information too timely and important to wait for those official channels? In what ways will the writer position herself vis-à-vis her audience? As an expert? As equals? As a novice?

At another level, writing can and will circulate once it is created. What keywords might be used to maximize how the writing will show up in a database search, or what tags might be embedded in the metadata of a blog post to make the writing more visible to search engines? Writers must understand that their products - whether focused or by-the-way - despite their potential ubiquity, will, primarily, only reach certain audiences in certain ways, making reasonable accommodations to help writing move through those communities and spaces. On the other hand, digital writing is potentially open for everybody due to technical mishaps or hacking.

These issues are also embedded in larger and controversial discussions about when, how, and why it is appropriate to take existing intellectual property and remix that material into one's own creation (e.g., Vie 2013). In the US, Lawrence Lessig has long been an outspoken advocate against our current, restrictive forms of copyright, and suggests that users appropriate copyrighted materials when creating new content (Lessig 2004, 2008). This also involves discussions of fair use, and the ways in which a writer might transform existing copyrighted materials (Hobbs 2010).

Each of these five dimensions, then, provide writing researchers with new lenses through which research begins to understand how and why writers make decisions with the tools they are afforded in today's digital world. Baron reminds us that 


\begin{abstract}
When we write with cutting-edge tools, it is easy to forget that whether it consists of energized particles on a screen or ink embedded in paper or lines gouged into clay tablets, writing itself is always first and foremost a technology, a way of engineering materials in order to accomplish an end. Tied up as it is with value-laden notions of literacy, art, and science, of history and psychology, of education, of theory, and of practicality, we often lose sight of writing as technology, until, that is, a new technology like the computer comes along and we are thrown into excitement and confusion as we try it on, try it out, reject it, and then adapt it to our lives-and of course, adapt our lives to it (Baron 2001: 71).
\end{abstract}

With these five dimensions over what writing is in mind - deliberateness, inclusiveness, connectedness, versatility, and openness - we now take a moment to consider what, if anything, writing is not.

\title{
4 Controversial issues: What's left that is not writing?
}

Given the vast array of ideas presented above with our five dimensions of writing, we begin to wonder: at what point are we investigating, practicing, or teaching something else - art, photography, music, document design, or other other categories of craftsmanship - and moving too far away from what it means to actually write? What about the ways in which we place words into sentences into paragraphs into longer narrative or expository pieces? At what point are we no longer really writing if we are spending more time on adjusting font size, finding the perfect picture to complement our blog post, or engaging in a fast-paced conversation via SMS? Again, we argue that writing is mindful engagement, whether focused or by-the-way. Writing is complex, significant, and discerning. Writing requires decision-making, not just stringing together a superficial, impromptu collection of words (or images or links or any other media). We know that writing allows us to be intentional, deliberate, and purposeful with our thoughts, feelings, and questions. We write to discover who we are and what we believe, and the five dimensions above capture these principles.

So, what would we consider to not be writing? Here is a partial list:

- A calligraphical task where someone is, for all intents and purposes, copying a sequence of signs or symbols and does not have to understand meaning in order to accomplish the task.

- A message posted to a social network that has not, at least for a moment, been thoughtfully considered by its sender as potentially helpful or harmful, humorous or offensive.

- An item - whether text, image, or video - which is simply taken from an original website and then repinned, reblogged, or retweeted, especially without attribution to the original creator. 
In short, what is not writing is anything that lacks intention and meaning; in other words writing must have pragmatic and semantic understanding. While a video shot with a cell phone camera may show a crime in progress and lead to a conviction, that video alone is not an act of writing. The video must, at the very least, go through a composition process where the videographer considers whether or not it would be appropriate to post it on the internet or share it with local authorities privately. If the video is to be posted online, the writer must also consider how to title the video, what description to provide, which key words to tag it with, and which social networks to distribute it on. Ideally, the composition might also include some editing with software on his phone - even if only minor - to include a time, date, and location in the title screen. That would be writing that includes a process of revision. We could make the case that a specific camera angle is an intentional choice that leads to an artistic effect, or that a filtered theme applied to the video may provide a thematic element, but this does not compare to a video that incorporates multiple camera angles, scenes, or transitions. In this example, the video is recorded and shared by-the-way, probably in the span of just a few minutes, and is not focused over an extended period of time. In any case, what matters is the writer's intention to develop, (re)construct, and communicate a semiotic composition, making decisions about purpose, audience, and distribution.

However, rather than debate what is not writing, it is much more interesting to think about examples of what we would consider to be purposeful, creative, and intentional forms of writing that include various forms of media and often transfer across different modes or genres.

\section{Outcome: Explaining writing as a core mode of real-life language use}

Writing has always been - and will continue to be - a core mode of real-life language use. Even in homes, schools, communities, or workplaces where writing may not be as valued a communicative form as speech, there are numerous examples of how written language still affects our lives. From a simple memo or to-do list, to a stylistically sophisticated love note, a carefully written email, or a short report for an insurance company, most people will use writing in their lives each day. Beyond these everyday uses, many people write to create, discover, inform, and argue through essays, articles, chapters, books, op-eds, scripts, and dozens of other genres.

Moreover, there are increasing numbers of examples of how multimodally oriented and multimedially displayed texts affect everyday life. From that same to-do list or love note that now comes as an SMS or tweet to the novel that is produced for reading on the web, we are ever more able to perform these types of multimodal, multimedia writing processes. Beginning in 2007, with the introduction of the iPhone, mobile users around the world have adopted smartphone technology that integrates 
cameras and microphones into their handheld, internet-connected computers. The ability to take pictures, shoot video, record sounds, and then use various applications and web-based services to combine, alter, or remix these forms of media has continued to increase. It is quite possible for a user - whether on vacation or for purposes of work - to create a digital video that documents a place or experience, post it to the internet, distribute the link via social networks, and then receive feedback on his or her creation within moments. No longer limited to text alone, writing, at least as focused writing, remains oriented towards thoughtful, intentionally-composed pieces.

To the extent that we want to encourage scholars to study both focused writing and writing-by-the-way in our increasingly globalized and networked world, we are fortunate to have a number of striking and useful examples of research approaches. The scholarly traditions of Sociolinguistics (2.1), New Literacy Studies (2.2), Digital Writing and Rhetoric (2.3), and Digital Humanities (2.4) all have something to offer us as we begin to think about innovative approaches to writing beyond single modes and media. Examples include:

- $\quad$ From a deliberateness perspective (3.1), change in media interacts with change in stance, content, and contextualization (e.g., Dilger 2010; Kress 2005; Prior 2005; Schmidt 2011).

- From an inclusiveness perspective (3.2), new media such as computer games influence - and alter the conception of - literacy (e.g., Alberti 2008).

- From a connectedness perspective (3.3), digital environments change the search for source texts and information (e.g., Puerta Melguizo et al. 2008; Purdy 2010).

- From a versatility perspective (3.4), web 2.0. environments foster writing-by-theway in templates, detaching writing from typography and design (e.g., Arola 2010).

- From an openness perspective (3.5), acquiring new literacies helps overcome digital gaps and social boundaries (e.g., Chandler and Scenters-Zapico 2012).

- At the interface of writing and technology in general, new tools shape human writing practices (e.g., Kirtley 2012; Mangen and Velay 2012; McGee and Ericsson 2002; Porter 2003) and help evaluate them (e.g., Cope et al. 2011).

Each of these research approaches offers scholars different ways to consider the process and outcomes of writing. And each approach is based on sophisticated theoretical (Donahue and Lillis; Prior and Thorne, this volume) and methodological (Grésillon and Perrin, this volume) reflection. Each is imbued with a different set of theoretical lenses, brought to life through the decisions researchers make about who and what to study, as well as how to present that argument to peers through journals, conference presentations, books, and conversations with the broader public. The history of scholars who are interested in the study of writing offers us a number of beginning points for productive inquiry, and future research can build new work based on their traditions and - and a spirit of remaining open to the unexpected. 


\section{Perspectives: Towards large-scale in-depth research of transmodal text production}

The need for a vision of future writing - and its research (e.g., McClure 2011) - is illustrated, for example, by a recent report jointly issued by the Pew Internet Research Project and the National Writing Project, "The Impact of Digital Tools on Student Writing and How Writing is Taught in Schools“ (Purcell, Buchanan, and Friedrich 2013). Here, the authors find that $96 \%$ of teachers feel that the technologies allow students to share their writing with a wider audience and that $79 \%$ feel these technologies encourage greater collaboration. Despite this seeming enthusiasm, most teachers report that the typical assignments are either a "short essay, short response or opinion piece” (Purcell, Buchanan, and Friedrich 2013: 15) although not necessarily with a digital writing tool. In fact, the most popular use of technology was to "[d]o research or search for information online" (Purcell, Buchanan, and Friedrich 2013: 48). Also, the types of written products do not necessarily embrace the types of digital possibilities afforded by various tools such as blogs, wikis, or collaborative word processors. Thus, even at a time when more teachers appear to be embracing digital writing in their classrooms, academic expectations and technological limitations also keep them from fully embracing this broader view of writing that includes hypertexts, multimodal compositions, or social networks.

In contrast to the above stance - and connecting back to focused writing and writing-by-the-way - we argue that the real-life uses of digital writing will continue, over time, to become the new communicative norm for our networked and globalized society. As we come to understand what the new social practices and technology platforms for writing will be, we have a number of useful examples. For instance, Ito et al. (2009) have documented the ways in which children and teens use technology; the title of their book, Hanging Out, Messing Around, and Geeking Out, offers three descriptions for what youth do in online spaces to build relationships and explore their interests. Howard Rheingold (2012) also offers five key strategies for "thriving online" that include paying attention, participating, utilizing collective intelligence, becoming part of a network, and learning "crap detection.” These mindful strategies merge both the social and the technical to help both researchers and practitioners understand how focused writing and writing-by-the-way can contribute to human agency as writers. Making conscious decisions about how to spend time online, how to create new texts, and how to circulate those texts amongst the various networks in which we participate is an important set of skills.

Therefore, while we understand that different scholars will look at focused writing with more esteem than writing-by-the-way, we also hope that we have made the case for a more integrative inquiry and rigorous scholarly investigation. Indeed, we must explore writing in its present and future forms as we continue to 
move forward with our research and teaching agendas. Here, we humbly offer a few suggestions for how to do so, as well as some questions to guide us in that inquiry process.

Table 1: Investigating writing across media and modes

\begin{tabular}{ll}
\hline Writing & Examples of activity fields and related \\
\cline { 2 - 2 } dimension & Focused Writing \\
\hline Deliberateness & In the traditions of good academic \\
Writing as an & and professional writing and debate, \\
intentional, & writing can be passionate yet purpo- \\
long-term activity & seful with a reliance on clear logic and \\
as well as an inci- & appropriate evidence gathered over \\
dental activity & time and across sources.
\end{tabular}

How can writers employ academic and professional skills for finding, analyzing, and synthesizing information while also relying on $R S S$ readers and news updates?

Inclusiveness Writing as a metaphor for producing and editing audio and video files, writing as speaking, speaking as writing

Connectedness Writing linear text as well as hypertexts in text ecologies and databases
Over time, using a process of brainstorming, drafting, revising, and then creating final edits, a composition can be refined and articulated through a variety of media. For instance, creating a podcast may involve interviewing and recording various participants, then editing that audio into a cohesive text.

In what ways can writers make informed decisions about using various forms of media to best reach an audience based on the needs, interests, and media best suited for them?

Websites and other multimodal texts offer their addressees an appropriate set of choices for interactivity, as well as using links to provide evidence and outside support.

Given the variety of media available, how can the writer make smart decisions about the words, images, design elements, hyperlinks, and navigation options that contribute to the intertextually connected meaning of a text?
Writing includes the collaborative construction of a single text (e.g., a Wikipedia page) or contributing smaller pieces to a larger text (e.g., using a hashtag to add a message to a Twitter stream). By-the-way contributions may be produced using alphabetic print, or with other media.

How can writers learn to work with one another with different media, both responding to and possibly critiquing the work of others while honoring their contributions to the whole?

Writers engage in interactive streams of communication using social networking or other instant messaging tools to contribute useful information and links to an on-going conversation.

In an effort to contribute valuable information to a conversation, how might a writer gather existing resources (e.g., links to websites, journal articles, etc.) that will enhance the overall experience? 


\begin{tabular}{|c|c|c|}
\hline \multirow{2}{*}{$\begin{array}{l}\text { Writing } \\
\text { dimension }\end{array}$} & \multicolumn{2}{|c|}{ Examples of activity fields and related research questions starting from ... } \\
\hline & Focused Writing & Writing-by-the-way \\
\hline $\begin{array}{l}\text { Versatility } \\
\text { Writing transient } \\
\text { text in interactive } \\
\text { online environ- } \\
\text { ments, writing } \\
\text { for small and big } \\
\text { screens }\end{array}$ & $\begin{array}{l}\text { Writing can - and increasingly has } \\
\text { to - be regarded as detached from } \\
\text { a specific material surface such as a } \\
\text { piece of paper or a screen layout. } \\
\text { Depending on where and how the } \\
\text { writer's work will be distributed, what } \\
\text { technologies will be most useful for } \\
\text { reading/viewing the text in the various } \\
\text { formats accessible for the addressees? }\end{array}$ & $\begin{array}{l}\text { The collaborative production and com- } \\
\text { munication of meaning in multimodal } \\
\text { texts is sourced and controlled by using } \\
\text { carefully written contributions, but also } \\
\text { by participating in continuous flows of } \\
\text { comments written by-the-way. } \\
\text { How can annotation tools for collabo- } \\
\text { rative text production be developed } \\
\text { towards multi-platform and mobile col- } \\
\text { laborative writing and text production? } \\
\text { And how can these tools be used most } \\
\text { productively? }\end{array}$ \\
\hline $\begin{array}{l}\text { Openness } \\
\text { Writing for media } \\
\text { that cross bound- } \\
\text { aries between } \\
\text { authors and } \\
\text { readers, indivi- }\end{array}$ & $\begin{array}{l}\text { Writers can be aware or not of where, } \\
\text { when, and how to share particular } \\
\text { forms of media and communicational } \\
\text { offers. They can also have or not have } \\
\text { the discretion not to share if inappro- } \\
\text { priate. }\end{array}$ & $\begin{array}{l}\text { Although the maxim that information } \\
\text { wants to be free has guided a generati- } \\
\text { onal ethos toward openness in digital } \\
\text { writing environments, writing-by-the- } \\
\text { way must also acknowledge the role of } \\
\text { copyright and intellectual property. }\end{array}$ \\
\hline $\begin{array}{l}\text { dual and collec- } \\
\text { tive addressees, } \\
\text { and private and } \\
\text { public access }\end{array}$ & $\begin{array}{l}\text { How do writers decide what message } \\
\text { they want to convey to whom? How } \\
\text { aware are writers and readers of } \\
\text { digital persistence and permeability? } \\
\text { How does writing change over time in } \\
\text { this context? }\end{array}$ & $\begin{array}{l}\text { How do speed, time pressure, and chan- } \\
\text { ging concepts such as authorship and } \\
\text { copyright affect formerly rigid conven- } \\
\text { tions of writing in writing-by-the-way } \\
\text { situations. }\end{array}$ \\
\hline
\end{tabular}

Writers will continue to take advantage of the technologies that are available to them. Whether these technologies are on their desktop, in their pocket, or even implanted into their bodies, the simple fact of the matter is that they are now connected, e.g. through the internet, and as bandwidth continues to grow so too will the possibilities for multimodal composing. The recent acquisition of Vine, a service that allows users to create 6 second videos, by the micro-blogging service Twitter demonstrates that, even in miniature chunks, composition still matters. Intention still matters. Writing may be produced by-the-way, or through focused development over time in handbook chapters, yet no matter how it is created we need to honor the experiences that writers bring to the task and, in turn, rethink the ways that we go about understanding textual production. 


\section{References}

Alberti, John. 2008. The game of reading and writing. How video games reframe our understanding of literacy. Computers and Composition 25(3): 258-269.

Alliance for Digital Humanities Organizations. n.d. About, http://adho.org/about, last accessed on 20.07.2013.

Anyon, Jean. 1997. Ghetto Schooling: A Political Economy of Urban Educational Reform. New York: Teachers College Press.

Arola, Kristin L. 2010. The design of web 2.0. The rise of the template, the fall of design. Computers and Composition 27(1): 4-14.

Ávila, JuliAnna and Jessica Z. Pandya. 2012. Critical Digital Literacies As Social Praxis: Intersections and Challenges. New York et al.: Peter Lang Publishing.

Baron, Dennis. 2001. From pencils to pixels: The stages of literacy. In: Ellen Cushman, Eugene R. Kintgen, Barry M. Kroll and Mike Rose (eds.), Literacy: A Critical Sourcebook, 70-84. Boston: Bedford/St. Martin's, http://www.english.illinois.edu/-people-/faculty/debaron/essays/ pencils.htm, last accessed on 13.10.2013.

Barton, David and Mary Hamilton. 1998. Local Literacies: Reading and Writing in One Community. London/ New York: Routledge.

Chafe, Wallace L. 2002. Writing in the perspective of speaking. In: Ellen Barton and Gail Stygall (eds.), Discourse Studies in Composition, 43-69. Cresskill, NJ: Hampton.

Chandler, Sally and John Scenters-Zapico. 2012. New literacy narratives. Stories about reading and writing in a digital age. Computers and Composition 29(3): 185-190.

Cope, Bill, Mary Kalantzis and New London Group. 2000. Multiliteracies: Literacy Learning and the Design of Social Futures. London/ New York: Routledge.

Cope, Bill, Mary Kalantzis, Sarah McCarthey, Colleen Vojak and Sonia Kline. 2011. Technologymediated writing assessments. Principles and processes. Computers and Composition 28(2): 79-96.

Council of Writing Program Administrators, National Councile of Teachers of English and National Writing Project. 2011. Framework for Success in Postsecondary Writing, http://wpacouncil.org/ framework/, last accessed on 12.08.2012.

Currie, Haver C. 1952. A projection of sociolinguistics. The relationship of speech to social status. Southern Speech Journal (18): 28-37.

Delpit, Lisa. 2006. Other People’s Children: Cultural Conflict in the Classroom. 1st edition. New York: New Press.

DeVoss, Danielle, Elyse Eidman-Aadahl and Troy Hicks. 2010. National Writing Project. Because Digital Writing Matters: Improving Student Writing in Online and Multimedia Environments. San Francisco, CA: Jossey-Bass.

DigiRhet.org. 2006. Teaching Digital Rhetoric: Community, Critical Engagement, and Application. Pedagogy: Critical Approaches to Teaching Literature, Language, Composition, and Culture 6: 231-260.

Dilger, Bradley. 2010. Beyond star flashes. The elements of web 2.0 style. Computers and Composition 27(1): 15-26.

Dyson, Anne H. 2003. The Brothers and Sisters Learn to Write: Popular Literacies in Childhood and School Cultures. Language and Literacy Series. New York/ London: Teachers College Press.

Fishman, Joshua A. 1972. The relationship between micro- and macro-sociolinguistics in the study of who speaks what language to whom and when. In: John Bernhard Pride and Janet Holmes (eds.), Sociolinguistics, 15-32. Harmondsworth: Penguin.

Gee, James P. 1996. Social Linguistics and Literacies: Ideology in Discourses. $2^{\text {nd }}$ edition. London/ Bristol, PA: Taylor \& Francis. 
Goodin, Dan. 2005. "Nature": Wikipedia is Accurate, http://www.usatoday.com/tech/news/2005-1214-nature-wiki_x.htm, last accessed on 03.11.2007.

Heath, Shirley B. 1983. Ways With Words: Language, Life, and Work in Communities and Classrooms. Cambridge: Cambridge University Press.

Hicks, Troy. 2013. Crafting Digital Writing: Composing Texts Across Media and Genres. Portsmouth, NH: Heinemann.

Hobbs, Renee. 2010. Copyright Clarity: How Fair Use Supports Digital Learning. Thousand Oaks, CA: Corwin Press.

Humanities, Arts, Science, and Technology Alliance and Collaboratory. n.d. About HASTAC, http:// hastac.org/about, last accessed on 20.07.2013.

Hymes, Dell. 1972. Models of the interaction of language and the social life. In: John J. Gumperz and Dell Hymes (eds.), Directions in Sociolinguistics. The Ethnography of Communication, 35-71. New York: Holt Rinehart and Winston.

International Telecommunications Union. 2013. The World in 2013: ICT Facts and Figures, http:// www.itu.int/en/ITU-D/Statistics/Documents/facts/ICTFactsFigures2013.pdf, last accessed on 12.10.2013.

Ito, Mizuko, Heather A. Horst, Matteo Bittanti, Danah Boyd, Becky Herr-Stephenson, Patricia G. Lange, C. J. Pascoe, Laura Robinson, Sonja Baumer, Rachel Cody, Dilan Mahendran, Katynka Z. Martínez, Dan Perkel, Christo Sims and Lisa Tripp (2009). Hanging Out, Messing Around, and Geeking Out: Kids Living and Learning With New Media. 1st edition. Cambridge, MA: The MIT Press.

Johnson-Eilola, Johndan and Amy C. Kimme Hea. 2003. After hypertext. Other ideas. Computers and Composition 20(4): 415-425.

Khondker, Habibul Haque. 2004. Glocalization as globalization. Evolution of a sociological concept. Bangladesh E-Journal of Sociology 1(2): 12-20.

Kirtley, Susan. 2012. Rendering technology visible. The technological literacy narrative. Computers and Composition 29(3): 191-204.

Knox, John S. 2009. Punctuating the home page: image as language in an online newspaper. Discourse \& Communication 3(2): 145-172.

Kress, Gunther. 2005. Gains and losses. New forms of texts, knowledge, and learning. Computers and Composition 22: 5-22.

Labov, William. 1972. Sociolinguistic Patterns. Philadelphia: University of Pennsylvania Press.

Lankshear, Colin and Michele Knobel. 2003. New Literacies: Changing Knowledge and Classroom Learning. Buckingham [England]; Philadelphia, Pa.: Society for Research into Higher Education \& Open University Press.

Lankshear, Colin and Michele Knobel. 2007. New Literacies: Everyday Practices and Classroom Learning. $2^{\text {nd }}$ edition. Berkshire, England/ New York, NY: Open University Press/McGraw-Hill.

Lankshear, Colin and Michele Knobel. 2011. New Literacies: Everyday Practices and Social Learning. $3^{\text {rd }}$ edition. Berkshire, England/ New York: Open University Press.

Lessig, Lawrence. 2004. Free Culture: How Big Media Uses Technology and the Law to Lock Down Culture and Control Creativity. New York: Penguin Press HC.

Lessig, Lawrence. 2008. Remix: Making Art and Commerce Thrive in the Hybrid Economy. New York: Penguin Press HC.

Ludwig, Otto. 2005. Geschichte des Schreibens. Vol. 1: Von der Antike bis zum Buchdruck. Berlin et al.: De Gruyter.

MacLeod, Jay. 1995. Ain't No Makin' it: Aspirations and Attainment in a Low-income Neighborhood. Boulder: Westview Press.

Madden, Mary, Amanda Lenhart, Maeve Duggan, Sandra Cortesi and Urs Gasser. 2013. Teens and Technology 2013. Pew Research Center's Internet and American Life Project, http://www. pewinternet.org/Reports/2013/Teens-and-Tech.aspx, last accessed on 09.06.2013. 
Mangen, Anne and Jean-Luc Velay. 2012. The haptics of writing. Cross-disciplinary explorations of the impact of writing technologies on the cognitive-sensorimotor process involved in writing. In: Mark Torrance, Denis Alamargot, Montserrat Castello, Franck Ganier, Otto Kruse, Anne Mangen, Liliana Tolchinsky and Luuk Van Waes (eds.), Learning to Write Effectively. Current Trends in European Research, 405-409. Bingley: Emerald.

McClure, Randall. 2011. WritingResearchWriting. The semantic web and the future of the research project. Computers and Composition 28(4): 315-326.

McGee, Tim and Patricia Ericsson. 2002. The politics of the program MS Word as the invisible grammarian. Computers and Composition 19(4): 453-470.

Mills, Kathy Ann. 2010. A Review of the "Digital Turn" in the New Literacy Studies. Review of Educational Research 80(2): 246-271.

Perrin, Daniel. 2012. Shaping the multimedia mindset. Collaborative writing in journalism education. In: Chris Thaiss and Gerd Bräuer (eds.), Writing programs worldwide. profiles of academic writing in many places, 389-400. Fort Collins: The WAC Clearinghouse and Parlor Press.

Porter, Jim. 2003. Why technology matters to writing. A cyberwriter's tale. Computers and Composition 20(4): 375-394.

Poulter, Martin. 2012. Writing for Wikipedia Has Forced Me into Good Scholarly Habits and Accessible Writing. Impact of Social Sciences, http://blogs.lse.ac.uk/impactofsocialsciences/2012/10/04/poulter-writing-wikipeda-scholarly-habits/, last accessed on 21.07.2013.

Prior, Paul. 2005. Moving multimodality beyond the binaries. A response to Gunther Kress' "Gains and Losses". Computers and Composition 22(1): 23-30.

Puerta Melguizo, Mari Carmen, Teresa Bajo, Gracia Castillo, Olga Muñoz and Lou Boves. 2008. A proactive recommendation system for writing in the internet age. Journal of Writing Research 2(1): 65-81.

Purcell, Kristen, Judy Buchanan and Linda Friedrich. 2013. The Impact of Digital Tools on Student Writing and How Writing is Taught in Schools. Pew Research Center's Internet \& American Life Project, http://pewinternet.org/Reports/2013/Teachers-technology-and-writing, last accessed on 12.10.2013.

Purdy, James P. 2010. The changing space of research. Web 2.0 and the integration of research and writing environments. Computers and Composition 27(1): 48-58.

Rheingold, Howard. 2012. Net Smart: How to Thrive Online. Cambridge, Mass.: The MIT Press.

Schmidt, Christopher. 2011. The new media writer as cartographer. Computers and Composition 28(4): 303-314.

Shirky, Clay. 2008. Here Comes Everybody: The Power of Organizing Without Organizations. New York et al.: Penguin Press HC, The.

Singer, Jane B. 2009. Convergence and divergence. Journalism 10(3): 375-377.

Street, Brian V 1984. Literacy in Theory and Practice. Cambridge [Cambridgeshire]/ New York: Cambridge University Press, http://www.loc.gov/catdir/description/cam022/83023938.html http://www.loc.gov/catdir/toc/cam022/83023938.html, last accessed on 12.10.2013.

Vie, Stephanie. 2013. A pedagogy of resistance toward plagiarism detection technologies. Computers and Composition 30(1): 3-15.

Weber, Wibke and Hannes Rall. 2012. Data Visualization in Online Journalism and Its Implications for the Production Process. In: Ebad Banissi et al. (eds.): Information Visualisation. 16th International Conference on Information Visualisation (IV 2012), Proceedings. IEEE Computer Society 2012, 349-356.

Wikimedia Foundation. n.d. Wikimedia Report Card. Wikimedia Report Card., http://reportcard. wmflabs.org/, last accessed on 02.08.2013.

Wikipedia. 2013a. In: Wikipedia, the free encyclopedia, https://en.wikipedia.org/w/index.php?title $=$ Wikipedia\&oldid $=564284941$, last accessed on 13.10.2013. 
Wikipedia: Neutral point of view. 2013b. In: Wikipedia, the free encyclopedia, https://en.wikipedia. org/w/index.php?title=Wikipedia:Neutral_point_of_view\&oldid=564390336, last accessed on 15.07.2013.

Wright, Patricia. 2012. Designing multimedia documents in the workplace. In: Mark Torrance, Denis Alamargot, Montserrat Castello, Franck Ganier, Otto Kruse, Anne Mangen, Liliana Tolchinsky and Luuk Van Waes (eds.), Learning to Write Effectively. Current Trends in European Research, 335-339. Bingley: Emerald.

Yang, Yu-Feng. 2012. Multimodal composing in digital storytelling. Computers and Composition 29(3): 221-238. 
